\title{
Assessment of Physical Activity in Patients with Chronic Low Back or Neck Pain
}

\author{
Kronik Bel Boyun Ăgrılı Hastalarda Fiziksel Aktivitenin \\ Değerlendirilmesi
}

\author{
Melda SOYSAL ${ }^{1}$, Bilge KARA ${ }^{1}$, M. Nuri ARDA ${ }^{2}$ \\ ${ }^{1}$ Dokuz Eylul University, School of Physical Therapy and Rehabilitation, Department of Physical Therapy, Inciralti, Izmir, Turkey \\ ${ }^{2}$ Dokuz Eylul University, Faculty of Medicine, Department of Neurosurgery, Inciralti, Izmir, Turkey
}

Correspondence address: Bilge KARA / E-mail: bparlak@deu.edu.tr

\begin{abstract}
AIM: To investigate physical activity level in patients with chronic low back and neck pain.

MATERIAL and METHODS: 32 preoperative patients, 32 outpatients with low back or neck pain and 32 healthy controls were included in study. The physical activity level of the participants was evaluated with the International Physical Activity Questionnaire. The Oswestry Disability Index and Neck Pain Disability Index, Short Form-36, Pittsburgh Sleep Quality Index and Beck Depression Inventory were used for assessment of disability, quality of life, sleep quality and depression.

RESULTS: Statistical significant differences was found in disability, sleep quality, depression, physical activity level and quality of life scores between three groups $(p<0.05)$. All scores of preoperative patients were significantly lower than outpatients except sleep parameter $(p<0.05)$. Sleep quality, disability and depression scores of patients with chronic neck pain were significantly lower and physical activity level and quality of life scores were significantly higher than patients' with chronic low back pain $(p<0.05)$.
\end{abstract}

CONCLUSION: Physical activity modification was found in patients with chronic low back and neck pain. Physical activity level, disability, sleep, depression and quality of life scores of preoperative patients with low back pain more affected than neck patients.

KEYWORDS: Physical activity, Chronic low back pain, Neck pain, Low back pain

öz

AMAÇ: Kronik bel-boyun ağrılı hastalarda fiziksel aktivite düzeyinin değerlendirilmesidir.

YÖNTEM ve GEREÇLER: Çalışmamıza operasyon planlanan 32, ayaktan poliklinik kontrolüne gelen KBBA'sı olan 32 olgu ve 32 kontrol alınmıştır. Olguların fiziksel aktivite düzeyleri 'Uluslararası Fiziksel Aktivite Anketi' ile ölçüldü. Özürlülük düzeylerinin değerlendirmesinde 'Oswestry Disabilite İndeksi ve 'Neck Pain Disability Index', yaşam kalitesi ölçümünde 'Kısa Form-36, uyku değerlendirmesinde 'Pittsburgh Uyku Kalite İndeksi, depresyon düzeylerinin ölçümünde 'Beck Depresyon Ölçeği' kullanıldı.

BULGULAR: Gruplar arasında özürlülük, uyku kalitesi, depresyon, fiziksel aktivite düzeyi ve yaşam kalitesi ölçeğinin alt parametrelerinde anlamlı fark bulundu $(p<0,05)$. Preoperatif hastaların uyku kalitesi dışındaki tüm değerlendirme sonuçları ayaktan gelen hastalardan anlamlı ölçüde düşüktü $(p<0,05)$. Boyun hastalarının uyku kalitesi, özürlülük ve depresyon skorları bel ağrılı hastalardan anlamlı ölçüde düşük, yaşam kalitesi ve fiziksel aktivite düzeyleri anlamlı ölçüde yüksek bulundu $(p<0,05)$.

SONUÇ: Kronik bel ve boyun ağrılı hastaların fiziksel aktivite düzeylerinde değişiklikler bulunmuştur. Bel ağrısı olup operasyon planlanan hastaların boyun hastalarına göre fiziksel aktivite düzeyi, özürlülük, uyku, depresyon, yaşam kalitesi parametreleri daha fazla etkilenmiştir.

ANAHTAR SÖZCÜKLER: Fiziksel aktivite, Kronik bel ağrısı, Boyun ağrısı, Bel ağrısı

\section{INTRODUCTION}

Chronic pain (consistent pain for more than 3 months) has a direct impact on quality of life, days off work, and healthcare costs $(8,19,50)$. Patients with chronic neck and low back pain (CLBNP) often report disability to perform daily activities. Attempting to explore the development of chronic disability, researchers have proposed a theoretical model linking initial pain with long-term disability via psychological distress, whereby the presence of pain induces psychological distress leading to ongoing disability (38). The impact of pain on daily living activities can be defined as a patient's disability level or decreased physical function. It is often assumed more disabled patients and thus those who report more daily life restrictions due to CLBNP will be those who are less physically active (25). A decreased physical activity level in daily life (disuse) has been presented as a perpetuating factor for chronicity in theoretical research models on pain $(17,47)$. Disuse again can lead to a decreased physical fitness level (e.g., obesity, decreased muscle strength and cardiovascular capacity $(13,36)$, which is often referred to as physical deconditioning $(39,7)$. Regular 
physical activity is widely believed to have important health benefits, such as improving quality of life and mobility, and reducing disabilities (2) Conversely, lack of physical activity is considered a risk factor for increasing chronic diseases, functional dependence and mortality (35). In many theoretical research models on pain and fatigue, a decreased level of physical activities (physical disuse) is assumed an important factor leading to and maintain chronicity of pain and fatigue $(17,49)$. These models suggest that as a consequence of longterm physical disuse, the condition of the patient gets worse, resulting in tiredness and pain during daily activities. This increases the fear of movement and thus the patient ends up in a vicious circle, characterized by a decrease in activities and an increase in psychological complaints (30). This theory is supported by several studies reporting on activity avoidance and physical functioning (e.g. muscle strength) in patients with chronic pain and fatigue $(12,37)$. Although there is no exact results about physical activity in patients with chronic neck pain, there is controversial results on that physical activity must be increased or reduced in studies for chronic low back pain.

The significance of physical activity in the management of low back pain (LBP) is generally accepted, and the increase in the level of physical activity has become an important part of recommendations in the management of low back pain (44). However, the development (or aetiology) of low back pain is poorly understood and the evidence of the contribution of physical activity to the prevalence, the prevention and management of low back pain is still inconclusive and poorly documented $(1,6)$. Physical activity has been suggested to be both a possible risk factor $(20,21,23,26)$ and a preventive factor $(3,15,16,22,32,40)$ for LBP. Some studies showed that patients with CLBP are less physically active or fit than healthy individuals $(3,21,23,32)$. Assessment of physical activity in patients with CLBNP is important point of planning treatment. The aim of this study was to assess physical activity level of patients with CLBNP.

\section{MATERIAL and METHODS}

\section{Participants}

Ninety six consecutive patients were enrolled into the study from the department of neurosurgery. The patients were divided into three groups. There were 32 participants in each group.

\section{Group 1: CLBNP outpatients}

\section{Group 2: CLBNP preoperative patients}

Group 3: Healthy individuals (control) in the same age group were enrolled into the study. Patients whose ages were between 35-70years, had chronic low back or neck pain (longer than 3 months), had no negative consequences for physical and/or mental functioning were included the study. Patients who were older than 70 years or had inflammatory spinal stenosis, neoplasms, neurologic deficits, with sequestrated disc herniation and more than two levels of symptomatic degenerative disc disease, significant osteoporosis, infection, etc., and had severe negative consequences for physical and/ or mental functioning (i.e., psychiatric disease, neurological problem) were excluded. It was determined that the patients included in the healthy group had not taken any medication. The patients who had pulmonary disease, uncontrolled cardiac dysfunction, head injury, were dependent of mobilization level, and neurological deficits were excluded in the first and second groups.

\section{Assessment of participants}

All patients and healthy individuals were assessed by an interview and demographic characteristics, medication consumption and previous physiotheraphy history were recorded. Disability severity, quality of life, sleep disturbances and depression that affect physical activity were assessed in all participants.

1. Disability: The Oswestry Disability Index (ODI; for patients with low back pain) and Neck Disability Index (NDI, for patients with neck pain) are self administered valid and reliable questionnaires used in the field of spinal research to indicate the extent to which a person's activities of daily living are disrupted or restricted by low back and neck pain $(11,46)$. They consist of ten items and are completed in reference to the patient's functional status 'today'. Each item contains six statements in both of these indexes (0-5 points). The total score is converted into a percentage score with $0-20 \%$ indicating minimal disability, $21-40 \%$ moderate disability, $41-60 \%$ severe disability, $61-80 \%$ crippled and $81-100 \%$ total incapacitation for ODI (51). A score between 0-4 points indicates no disability, score between 5-14 points indicates mild disability, score between $15-24$ points indicates moderate disability, score between $25-34$ points indicates severe disability and over 35 points indicates complete disability according to NDI (46).

2. Physical activity: Physical activity level was evaluated by the short form of the International Physical Activity Questionnaire (IPAQ). IPAQ is a scale to be recorded at different levels of physical activity time in the last week. The short version ( 9 items) provides information on the time spent walking, in vigorous- and moderate-intensity activity and in sedentary activity. Individuals whose score is lower than 600 MET are described as inactive, between 600-1500 MET are described as minimal active and higher than 3000 MET are described as active (9).

3. Quality of life: The health related quality of life was assessed using the Short Form-36 (SF-36) questionnaire. The SF-36 comprises eight multi item dimensions which are physical functioning, role physical, vitality, social functioning, role emotional, and bodily pain. Each of the dimensions is scored from 0 to 100 and with the higher scores indicating better health related quality of life except pain (24).

4. Sleep: The Pittsburgh Sleep Quality Index (PSQI) evaluates sleep quality and disturbances. The PSQI discriminates between good and poor sleepers and provides a brief, clinically useful assessment of multiple sleep disturbances. It 
consists of 19 items that generate seven component scores. The sum of these scores (range 0 - 21) yield a global measure of sleep quality, with higher scores indicating increasingly poor sleep (> 5 indicative of sleep disturbance). The components assess a broad range of domains associated with sleep quality including duration of sleep, sleep latency, the frequency and severity of specific sleep related problems and the perceived impact of poor sleep on daytime functioning $(10,31)$.

5. Depression:The Beck Depression Inventory is a 21-question multiple choice self report inventory, one of the most widely used instruments for measuring the severity of depression. The questionnaire is designed for individuals aged 13 and over. It is composed of items such as hopelessness and irritability, cognitions such as guilt and physical symptoms as fatigue, weight loss. The sum of the scores $>17$ indicates clinical depression $(4,18)$.

Ethical Committee: The study was approved by the local ethical committee and informed consent was obtained from the patients before inclusion. Ethical protocol number was 574-GOA.

\section{Statistical analysis}

Statistical analysis was performed using SPSS version 15.0 for Windows. Descriptive statistics include frequency distribution of categorical variables as well as mean and standard deviations for continuous variables. Results were presented as $\%$ and mean \pm SD. The parametric t-test was used for comparison of group results. ANOVA was used for variance analysis of the results. The Bonferroni correction was used for counteract the problem of multiple comparisons. The correlation between results of all questionnaires between three groups were calculated by Pearson's correlation coefficient ( $r$ ). A p value of $<0.05$ was considered as statistically significant and the confidence interval was $95 \%$.

\section{RESULTS}

The demographical characteristics such as gender, mean age and Body Mass Index (BMI) of all groups were found to be similar and both groups were found to be similar when groups were separated as neck and back pain $(p<0.05$, Table I).

The mean medication consumption (analgesics) was $65.6 \%$ in preoperative patients (Group II) and $62.5 \%$ in outpatients (Group I). Statistical significance differences was found in disability, sleep disturbance, depression, physical activity level and subparameters of quality of life scores between three groups. All scores of Group I were significantly lower than Group II except sleep parameter. All parameters of the control group were significantly higher than other groups. Statistical significant differences appeared in Group II according to Bonferroni correction. Sleep quality, disability and depression scores of patients with chronic neck pain were significantly lower and also physical activity level and quality of life scores were significantly higher than patients' with chronic low back pain when comparing by pain area $(p<0.05$, Table II).

It was found that disability and depression scores were significantly positively correlated with physical activity level in group II (disability $r=0.430, p=0.014$; depression $r=0.680$, $p=0.000$ ) and group III (disability $r=0.363, p=0.041$, depression $r=0.360, p=0.43)$. There was no significant correlation between sleep quality and physical activity in all three group (Group I: $r=-0.266, p=0.141$; Group II: $r=-0.047, p=0.799$; Group III: $r=0.146, p=0.426)$. It was observed that there is no effect of physical activity on disability $(p=0.537)$, depression $(p=0.343)$ and sleep $(p=0.426)$ in Group III.

It was found that physical activity was correlated with the physical function and vitality subparameters of health related quality of life in all groups (Outpatients: $r=0.416, p=0.018$;

Table I: Demographic Characteristics of Participants

\begin{tabular}{|c|c|c|c|c|c|c|c|}
\hline \multirow[b]{2}{*}{ Gender } & \multicolumn{2}{|c|}{ Group I } & \multicolumn{2}{|c|}{ Group II } & \multicolumn{2}{|c|}{ Group III } & \multirow{2}{*}{$\begin{array}{c}p \text { value } \\
X^{2} \quad D F=p\end{array}$} \\
\hline & $\%$ & $\mathrm{n}$ & $\%$ & $\mathrm{n}$ & $\mathrm{n}$ & $\%$ & \\
\hline $\begin{array}{l}\text { NECK } \\
\text { Female } \\
\text { Male }\end{array}$ & $\begin{array}{r}17 \\
9 \\
8\end{array}$ & $\begin{array}{l}53.1 \\
28.1 \\
25.0\end{array}$ & $\begin{array}{r}26 \\
15 \\
9\end{array}$ & $\begin{array}{l}81.2 \\
46.9 \\
28.1\end{array}$ & $\begin{array}{r}21 \\
12 \\
9\end{array}$ & $\begin{array}{l}65.6 \\
37.5 \\
28.1\end{array}$ & $\begin{array}{l}0.367 \\
0.396 \\
0.289\end{array}$ \\
\hline Gender & $\%$ & $\mathrm{n}$ & $\%$ & $n$ & $\mathrm{n}$ & $\%$ & \\
\hline $\begin{array}{l}\text { BACK } \\
\text { Female } \\
\text { Male }\end{array}$ & $\begin{array}{r}15 \\
11 \\
4\end{array}$ & $\begin{array}{l}46.9 \\
34.4 \\
12.5\end{array}$ & $\begin{array}{l}6 \\
4 \\
2\end{array}$ & $\begin{array}{r}18.8 \\
12.6 \\
6.2\end{array}$ & $\begin{array}{r}11 \\
7 \\
4\end{array}$ & $\begin{array}{l}34.4 \\
21.9 \\
12.5\end{array}$ & $\begin{array}{l}0.428 \\
0.433 \\
0.401\end{array}$ \\
\hline Age (years) & \multicolumn{2}{|c|}{$52.16 \pm 5.05$} & \multicolumn{2}{|c|}{$53.78 \pm 6.69$} & \multicolumn{2}{|c|}{$53.47 \pm 4.82$} & 0.469 \\
\hline $\begin{array}{l}\text { Neck Patients } \\
\text { Back Patients }\end{array}$ & \multicolumn{2}{|c|}{$\begin{array}{l}50.87 \pm 4.52 \\
52.88 \pm 5.32\end{array}$} & \multicolumn{2}{|c|}{$\begin{array}{l}53.24 \pm 5.41 \\
54.01 \pm 6.86\end{array}$} & \multicolumn{2}{|c|}{$\begin{array}{l}52.02 \pm 4.64 \\
53.87 \pm 5.01\end{array}$} & $\begin{array}{l}0.396 \\
0.478\end{array}$ \\
\hline BMI* $\left(\mathrm{kg} / \mathrm{m}^{2}\right)$ & \multicolumn{2}{|c|}{$26.70 \pm 2.64$} & \multicolumn{2}{|c|}{$26.15 \pm 3.23$} & \multicolumn{2}{|c|}{$25.09 \pm 3.15$} & 0.764 \\
\hline $\begin{array}{l}\text { Neck Patients } \\
\text { Back Patients }\end{array}$ & \multicolumn{2}{|c|}{$\begin{array}{l}25.99 \pm 3.00 \\
26.89 \pm 2.79\end{array}$} & \multicolumn{2}{|c|}{$\begin{array}{l}25.79 \pm 4.84 \\
26.53 \pm 5.03\end{array}$} & & & \\
\hline
\end{tabular}

*BMI: Body Mass Index. 
Table II: Clinical Outcome Measures of Participants

\begin{tabular}{|c|c|c|c|c|}
\hline & Group I & Group II & Group III & $\mathbf{p}$ \\
\hline $\begin{array}{l}\text { Sleep quality } \\
\text { Neck } \\
\text { Back }\end{array}$ & $\begin{array}{l}13.81 \pm 3.18 \\
12.54 \pm 3.79 \\
14.44 \pm 4.84\end{array}$ & $\begin{array}{c}10.66 \pm 2.27 \\
9.06 \pm 3.06 \\
10.99 \pm 3.02\end{array}$ & 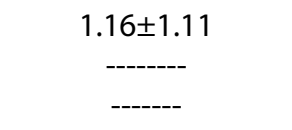 & 0.001 \\
\hline $\begin{array}{c}\text { Disability } \\
\text { Neck } \\
\text { Back }\end{array}$ & $\begin{array}{l}34.78 \pm 13.53 \\
31.83 \pm 20.13 \\
36.05 \pm 11.00\end{array}$ & $\begin{array}{c}39.03 \pm 9.61 \\
35.86 \pm 8.42 \\
42.28 \pm 12.95\end{array}$ & $\begin{array}{c}12.85 \pm 2.59 \\
-----\end{array}$ & 0.002 \\
\hline $\begin{array}{l}\text { Physical activity level } \\
\text { Neck } \\
\text { Back }\end{array}$ & $\begin{array}{l}6536.66 \pm 3639.25 \\
8483.49 \pm 2089.76 \\
5843.14 \pm 2906.85\end{array}$ & $\begin{array}{c}3354.66 \pm 1087.25 \\
4047.23 \pm 1986.02 \\
2739.04 \pm 968.39\end{array}$ & $\begin{array}{c}14481.44 \pm 1834.88 \\
------ \\
----\end{array}$ & 0.001 \\
\hline $\begin{array}{c}\text { Depression } \\
\text { Neck } \\
\text { Back }\end{array}$ & $\begin{array}{l}12.22 \pm 5.34 \\
10.88 \pm 4.96 \\
14.02 \pm 4.61\end{array}$ & $\begin{array}{c}14.37 \pm 6.99 \\
11.23 \pm 3.28 \\
15.05 \pm 2.99\end{array}$ & $\begin{array}{c}2.94 \pm 3.60 \\
------ \\
------\end{array}$ & 0.002 \\
\hline \multicolumn{5}{|l|}{ Quality of Life } \\
\hline Physical func. & $21.58 \pm 2.61$ & $20.63 \pm 3.77$ & $58.97 \pm 5.34$ & 0.001 \\
\hline Role physical & $29.29 \pm 9.37$ & $19.81 \pm 6.45$ & $57.74 \pm 10.82$ & 0.010 \\
\hline Pain & $30.01 \pm 3.92$ & $23.94 \pm 4.27$ & $63.87 \pm 10.41$ & 0.002 \\
\hline General health & $28.39 \pm 7.39$ & $18.92 \pm 5.46$ & $54.73 \pm 10.28$ & 0.010 \\
\hline Vitality & $21.69 \pm 2.63$ & $20.90 \pm 3.77$ & $59.49 \pm 5.37$ & 0.002 \\
\hline Social func. & $30.59 \pm 4.11$ & $24.59 \pm 4.07$ & $63.91 \pm 10.43$ & 0.010 \\
\hline Emotional role & $21.88 \pm 2.52$ & $24.07 \pm 3.86$ & $63.87 \pm 10.41$ & 0.010 \\
\hline Mental health & $30.54 \pm 4.19$ & $24.64 \pm 4.07$ & $64.04 \pm 10.47$ & 0.010 \\
\hline
\end{tabular}

$r=0.457, p=0.007$ Preoperative patients: $r=0.361, p=0.043$; $r=0.363, p=0.041$ Control group: $r=0.524, p=0.002 ; r=0.558$, $p=0.001$ ).

\section{DISCUSSION}

The demographic characteristics of all participants were found to be similar and group characteristics were homogeneous in this study evaluating physical activity in patients with chronic low back and neck pain.

Chronic neck and low back pain causes work loss, disability and depression, sleep problems. These problems decrease physical activity of patients with chronic pain (43). There is a little evidence for a relationship between physical activity an the complex of disability, sleep and depression in both chronic low back and neck pain. We investigated the effectiveness of physical activity on disability, sleep quality and depression in patients with chronic low back or neck pain who were in Group I and II.

Recent studies show that patients with chronic spinal pain have impaired daily activities. The daily function of the patients reduces due to chronic pain and disability may occur. More disabled patients report less physical activity (25). The physical activity level of preoperative patients was significantly lower than outpatients. Statistical significance differences was found in disability, sleep disturbance, depression, physical activity level and subparameters of quality of life scores between the three groups. All evaluation results that effect physical activity of preoperative patients including disability, depression and quality of life, was found significantly lower than outpatients except sleep quality in our study. A relationship between physical activity level and disability has been found in studies $(5,45)$. Lin et al. found a moderate correlation between physical activity level and disability in patients with chronic low back pain in the study that searching for the relationship between physical activity and disability. They advocated patients with chronic low back pain had high disability levels and low physical activity. They found no correlation between physical activity and disability in acute patients. According to their results they said patients in acute phase could change their behavioral activity strategies with reinjury fear (27). Parallel to the literature, preoperative patients were more disabled and decreased physical activity level than outpatient ones in our study. We did not evaluate acute low or back pain patients but both chronic low back and neck patients were minimally active compared to healthy subjects in present study. There are many studies in the literature about neck pain but no study that compare physical activity and its effectiveness on other parameters in patients with low back and neck pain. Physical activity and its effectiveness on disability, sleep quality, depression and quality of life was evaluated and results were compared between patients with chronic neck and low back pain. Physical activity of patients with chronic low back pain were significantly lower than patients with chronic neck pain. 
Disability, depression and sleep quality scores of patients with chronic low back pain were significantly higher and physical activity and quality of life scores lower than patients with chronic neck pain when patients are separated according to pain areas. Patients with chronic low back pain could feel more disabled because of lower extremity and lumbopelvic involvement compared to neck patients based on these results. Disability, depression, physical functions and vitality subparameters of quality of life were correlated with physical activity in both preoperative and outpatient groups. In addition to this result, pain and social function parameters of quality of life scores of outpatients were significantly negatively correlated with physical activity level. Patients in the chronic phase can feel much more pain or depression and may decrease their physical activity levels. Social isolation may occur and their quality of life may reduce.

The effect of physical activity on quality of life causes some problems such as sleep and depression. It's indicated that increased interleukin 6 level involved in pain processes and contribute to the sleep complaints in the literature $(29,48)$. Sleep disturbance has been found to have negative effect on mood $(34,42)$. The current studies show pain related sleep problems are associated with depression $(34,30,28)$. Hall et al. found depression symptoms were present 6 weeks after the onset of pain (14). Preoperative patients were more disabled and have had more depression compared to outpatients in our study. Pain parameter of quality of life was significantly higher and sleep quality was lower than outpatient group. According to these results, medication may have helped to improve sleep quality in preoperative patients. Consideration of the use of analgesics is important in the preoperative evaluation of patients with chronic neck and low back pain.

Limitations of study: The study was designed with chronic neck and back pain preoperative patients and outpatients. The physical activity level of preoperative patients was affected negatively by analgesic consumption and time of hospitalization. Further assessment should be done to find more accurate and efficient results. The results may also become more relevant if more patients are included.

\section{CONCLUSION}

Changes in the level of physical activity level were found in patients with chronic neck and low back pain. Physical activity level is much more affected than the sleep quality, depression and quality of life parameters in those who had low back pain and preoperative patients than others. Evaluation of parameters affecting the level of physical activity is very important and should be considered in planning the treatment of patients so that they can return to their daily lives.

\section{REFERENCES}

1. Abenhaim L, Rossignol $M$, Valat JP, Nordin $M$, Avouac $B$, Blotman F, Charlot J, Dreiser RL, Legrand E, Rozenberg S, Vautravers P: The role of activity in the therapeutic management of back pain. Report of the International Paris Task Force on Back Pain. Spine 25: 1-33, 2000
2. Ainsworth BE, Youmans CP: Tools for physical activity counseling in medical practice. Obes Res 10 (suppl 1): 69-75, 2002

3. Auvinen J, Tammelin T, Taimela S, Zitting P, Karppinen J: Associations of physical activity and inactivity with low back pain in adolescents. Scand J Med Sci Sports 18: 188-194, 2008

4. Beck AT, Ward $\mathrm{CH}$, Mendelson M, Mock J, Erbaugh J: An inventory for measuring depression. Arch Gen Psychiatry 4: 561-571, 1961

5. Bousema EJ, Verbunt JA, Seelen HAM, Vlaeyen JWS, Andre Knottnerus J: Disuse and physical deconditioning in the first year after the onset of back pain. Pain 130: 279-286, 2007

6. Campello $M$, Nordin M, Weiser S: Physical exercise and low back pain. Scand J Med Sci Sports 6: 63-72, 1996

7. Convertino VA, Bloomfield SA, Greenleaf JE: An overview of the issues: Physiological effects of bed rest and restricted physical activity. Med Sci Sports Exerc 29: 187-190, 1997

8. Co^te' P, van der Velde G, Cassidy JD, Carroll LJ, Hogg-Johnson S, Holm LW, Garragee EJ, Haldeman S, Nordin M, Hurwitz EL, Guzman J, Peloso PM: The burden and determinants of neck pain in workers. Results of the bone and joint decade 20002010 task force on neck pain and its associated disorders. Eur Spine J 17: 60-74, 2008

9. Craig $C$, Marshall $A$, Sjostrom $M$, Bauman $A$, Booth $M$, Ainsworth B, Pratt M, Ekelund U, Yngve A, Sallis JF, Oja P: International Physical Activity Questionnaire: 12 country reliability and validity. Med Sci Sports Exerc 35 (8): 1381-1395, 2003

10. Currie SR, Wilson KG, Curran D: Clinical significance and predictors of treatment response to cognitive behavioral therapy for insomnia secondary to chronic pain. Journal of Behavioral Medicine 25: 135-153, 2002

11. Fairbank J, Pynsent P: The Oswestry Disability Index. Spine 25: 2940-2953, 2000

12. Geisser ME, Robinson ME, Miller QL, Bade SM: Psychosocial factors and functional capacity evaluation among persons with chronic pain. J Occup Rehabil 13: 259-276, 2003

13. Greenleaf JE: Intensive exercise training during bed rest attenuates deconditioning. Med Sci Sports Exerc 29: 207-215, 1997

14. Hall AM, Kamper SJ, Maher CG, Latimer J, Ferreira ML, Nicholas MK: Symptoms of depression and stres mediate the effect of pain on disability. Pain 152: 1044-1051, 2011

15. Harreby M, Hesselsoe G, Kjer J, Neergaard K: Low back pain and physical exercise in leisure time in 38-year-old men and women: A 25-year prospective cohort study of 640 school children. Eur Spine J 6: 181-186, 1997

16. Hartvigsen J, Christensen K: Active lifestyle protects against incident low back pain in seniors: A population-based 2-year prospective study of 1387 Danish twins aged 70-100 years. Spine 32: 76-81, 2007

17. Hasenbring M, Marienfeld G, Kuhlendahl D, Soyka D: Risk factors of chronicity in lumbar disc patients. A prospective investigation of biologic, psychologic, and social predictors of therapy outcome. Spine 19: 2759-2765, 1994 
18. Hisli N: Reliability and validity of Beck Depression Inventory among university students. J Turk Psychol 7: 3-13, 1989

19. Hogg-Johnson S, van der Velde G, Carroll LJ, Holm LW, Cassidy JD, Guzman J, Cote P, Haldeman S, Ammendolia C, Carragee E, Hurwitz E, Nordin M, Peloso P: The burden and determinants of neck pain in the general population. Results of the bone and joint decade 2000-2010 task force on neck pain and its associated disorders. Eur Spine J 17: 39-51, 2008

20. Hoogendoorn WE, van Poppel MN, Bongers PM, Koes BW, Bouter LM: Physical load during work and leisure time as risk factors for back pain. Scand J Work Environ Health 25: 387-403, 1999

21. Hoogendoorn WE, Bongers PM, Vet de HCW, van Mechelen W, Bouter LM: High physical work load and low job satisfaction increase the risk of sickness absence due to low back pain: Results of a prospective cohort study. Occup Environ Med 59: 323-328, 2002

22. Hurwitz EL, Morgenstern H, Chias C: Effects of recreational physical activity and back exercises on low back pain and psychological distress: Findings from UCLA Low Back Pain Study. Am J Public Health 95: 1817-1824, 2005

23. Jacob T, Baras M, Zeev A, Epstein L: Physical activities and low back pain: A community-based study. Med Sci Sports Exerc 36: 9-15, 2004

24. Kocyigit H, Aydemir O, Fisek G, Olmez N, Memis A: Kısa Form36 'nin Turkce versiyonunun guvenilirligi ve gecerliligi. Ilac ve Tedavi Dergisi 12: 102-106, 1999

25. Koes B, van Tulder M, Lin C, Macedo L, McAuley JH, Maher C: An updated overview of clinical guidelines for the management of nonspecific low back pain in primary care. Eur Spine J 19: 2075-2094, 2010

26. Kujala UM, Taimela S, Viljanen T, Jutila H, Viitasalo JT, Videman T, Battié MC: Physical loading and performance as predictors of back pain in healthy adults: A 5-year prospective study. Eur J Appl Physiol 73: 452-458, 1996

27. Lin CWC, McAuley JH, Macedo L, Barnett DC, Smeets RJ, Verbunt JA: Relationship between physical activity and disability in low back pain: A systematic review and metaanalysis. Pain 152: 607-613, 2011

28. Marchand F, Perretti M, McMahon SB: Role of the immune system in chronic pain. Nat Rev Neurosci 6: 521-532, 2005

29. Marty M, Rozenberg S, Duplan B, Thomas P, Duquesnoy B, Allaert F: Quality of sleep in patients with chronic low back pain: a case-control study. Eur Spine J 17: 839-844, 2008

30. Mayer T, Tabor J, Bovasso E, Gatchel RJ: Physical progress and residual impairment quantification after functional restoration. Part 1: lumbar mobility. Spine 19: 389-394, 1994

31. Menefee LA, Cohen MJ, Anderson WR, Doghramji K, Frank $E D$, Lee $\mathrm{H}$ : Sleep disturbance and nonmalignant chronic pain: A comprehensive review of the literature. Pain Med 1: $156-172,2000$

32. Mikkelsson LO, Nupponen $H$, Kaprio J, Kautiainen $H$, Kujala UM: Adolescent flexibility, endurance strength, and physical activity as predictors of adult tension neck low back pain, and knee injury: a 25-year follow up study. Br J Sports Med 40: 107-113, 2006

33. Moldofsky H: Sleep and pain. Sleep Med Rev 5: 385-396, 2001
34. Morin CM, Gibson D, Wade J: Self-reported sleep and mood disturbance in chronic pain patients. Clin J Pain 14: 311-314, 1998

35. Mouton CP, Calmbach WL, Dhanda R, Espino DV, Hazuda H: Barriers and benefits to leisure-time physical activity among older Mexican Americans. Arch Fam Med 9: 892-897, 2000

36. Musacchia XJ, Steffen JM, Fell RD: Disuse atrophy of skeletal muscle: Animal models. Exerc Sport Sci Rev 16: 61-87, 1988

37. Neerinckx E, Van Houdenhove B, Lysens $R$, Vertommen $H$, Onghena P: Attributions in chronic fatigue syndrome and fibromyalgia syndrome in tertiary care. J Rheumatol 27: 1051-1055, 2000

38. Pincus T, Vogel S, Burton AK, Santos R, Field AP: Fear avoidance and prognosis in back pain-a systematic review and synthesis of current evidence. Arthritis Rheum 54: 3999-4010, 2006

39. Pratley R, Nicklas B, Rubin M, Miller J, Smith A, Smith M, Hurley $B$, Goldberg A: Strength training increases resting metabolic rate and norepinephrine levels in healthy 50 - to 65 -yr-old men. J Appl Physiol 76: 133-137, 1994

40. Sjolie AN: Associations between activities and low back pain in adolescents. Scand J Med Sci Sports 14: 352-359, 2004

41. Smith MT, Haythornthwaite JA: How do sleep disturbance and chronic pain inter-relate? Insights from the longitudinal and cognitive behavioral clinical trials literature. Sleep Med Rev 8: 119-132, 2004

42. Tucer B, Yalcin BM, Ozturk A, Mazicioglu MM, Yilmaz Y, Kaya $M$ : Risk factors for low back pain and its relation with pain related disability and depression in a Turkish sample. Turk Neurosurg 19: 327-332, 2009

43. van der Berg-Emons RJ, Schasfoort FC, de Vos LA, Bussmann JB, Stam HJ: Impact of chronic pain on everyday physical activity. Eur J Pain 11: 587-593, 2007

44. van Tulder MW, Koes BW, Bouter LM: A cost-of-illness study of back pain in the Netherlands. Pain 62: 233-240, 1995

45. van Weering $M$, Vollenbroek-Hutten MMR, Kotte Roessingh MMR, Hermens HJ: Daily physical activities of patients with chronic pain or fatigue versus asymptomatic controls. A systematic review. Clin Rehabil 21: 1007-1023, 2007

46. Vernon $\mathrm{H}$, Mior S: The neck disability index: A study of reliability and validity. J Manipulative Physiol Ther 14 (7): 409-415, 1991

47. Vlaeyen JW, Kole-Snijders AM, Boeren RG, van Eek H: Fear of movement/ (re)injury in chronic low back pain and its relation to behavioral performance. Pain 62: 3-72, 1995

48. Watkins LR, Maier SF: The pain of being sick: Implications of immune-to-brain communication for understanding pain. Annu Rev Psychol 51: 29-57, 2000

49. Wessely S, Butler S, Chalder T, David A: The cognitive behavioural management of post-viral fatigue syndrome. Wiley 305-315, 1991

50. Wolff R, Clar C, Lerch C, Kleijnen J: Epidemiology of chronic non-malignant pain in Germany. Schmerz 25: 26-44, 2011

51. Yakut E, Duger T, Oksuz C, Yorukan S, Ureten K, Turan D, Firat T, Kiraz S, Krd N, Kayhan H, Yakut Y, Guler C: Validation of the Turkish version of the Oswestry Disability Index for patients with low back pain. Spine 29 (5): 581-585, 2004 